\title{
TOPMODEL Hydrometeorological Modeling with Rain Gauge Data Integrated by High-Resolution Satellite Estimates. A Case Study in Muriaé River Basin, Brazil
}

\author{
Marcos Figueiredo Salviano ${ }^{1,2} \mathbb{1}$, Augusto José Pereira Filho² ${ }^{(0)}$, \\ Felipe Vemado² \\ ${ }^{1}$ Geological Survey of Brazil, São Paulo, Brazil \\ ${ }^{2}$ Departamento de Ciências Atmosféricas, Instituto de Astronomia, Geofísica e Ciências Atmosféricas, Universidade de São Paulo, \\ São Paulo, Brazil \\ Email: marcos.salviano@cprm.gov.br, augusto.pereira@iag.usp.br, fvfelp@gmail.com
}

How to cite this paper: Salviano, M.F. Filho, A.J.P. and Vemado, F. (2021) TOPMODEL Hydrometeorological Modeling with Rain Gauge Data Integrated by High-Resolution Satellite Estimates. A Case Study in Muriaé River Basin, Brazil. Atmospheric and Climate Sciences, 11, 486-507.

https://doi.org/10.4236/acs.2021.113029

Received: April 27, 2021

Accepted: June 13, 2021

Published: June 16, 2021

Copyright $\odot 2021$ by author(s) and Scientific Research Publishing Inc. This work is licensed under the Creative Commons Attribution International License (CC BY 4.0).

http://creativecommons.org/licenses/by/4.0/

\section{(c) (i) Open Access}

\begin{abstract}
This study consists of hydrological simulations of the Muriaé river watershed with the topography-based hydrological model (TOPMODEL) and available stream gauge and rain measurements between 2009 and 2013 for two subbasins, namely Carangola and Patrocínio do Muriaé. The simulations were carried out with the Climate Prediction Center morphing method (CMORPH) precipitation estimates and rain gauge measurements integrated into $\mathrm{CM}$ ORPH by the Statistical Objective Analysis Scheme (SOAS). TOPMODEL calibration was performed with the shuffled complex evolution (SCE-UA) method with Nash-Sutcliffe efficiency (NSE). The best overall results were obtained with CMORPH (NSE 0.6) for both subbasins. The simulations with SOAS resulted in an NSE $\sim 0.2$. However, in an analysis of days with highlevel stages, SOAS simulations resulted in a better hit rate (23\%) compared to CMORPH (10\%). CMORPH simulations underestimated the flows at the flood periods, which indicates the importance to use multi-sensor precipitation data. The results with TOPMODEL allow an estimate of future discharges, which allows for better planning of a flood warning system and discharge measurement schedule.
\end{abstract}

\section{Keywords}

Hydrologic Model, CMORPH, Statistical Objective Analysis Scheme (SOAS), TOPMODEL, Muriaé River 


\section{Introduction}

Floods are a natural phenomenon, but when occurring in inhabited areas they become natural disasters. Brazil is among the most affected countries, with 10,444 events recorded between 1991 and 2010, which resulted in more than 38 million people affected [1]. Urban expansion associated with socioeconomic problems acts in the increase and intensification of natural disasters related to floods. This is due to changes in the original hydrological cycle, such as increased soil waterproofing, deforestation, erosion, and structural interventions in rivers [2] [3]. The population (mainly low income) increase in hazardous areas enhances the magnitude of natural disaster's impact [4]. The effects on the affected population can be diverse and quite significant: direct deaths, destruction of buildings, evictions, disruption of dikes and dams, and obstruction of roads [5]. The economic damage caused by natural disasters is also significant, as it is estimated that in 2008 alone it was approximately US\$ 1 billion [6].

In Brazil, the South and Southeast regions, the latter where the Muriae river basin (hereafter, MRB) is located, is the most affected by natural disasters caused by hydrological phenomena [6]. Severe floods were recorded in the MRB in 1997, 2008, and 2012 [7]. Most recently in 2020, intense precipitations resulted in severe floods and landslides, which 84 cities located at or near the MRB the state of emergency was decreed with 7 deaths and 40,000 unsheltered people [8].

One alternative to better understand hydrological phenomena is through hydrological models. They make it possible to study the impact of land-use changes in a watershed and the prediction of flood events [9]. In a study in the Paraiba do Sul basin (in which the MRB is located) Caluan \& Cardoso (2020) [10] used a hydrological model to conclude that an increase in forest cover would decrease the frequency of very high flow events in the rainy season and also decrease the frequency of very low flow events in the dry months. Hydrological models can be defined as the representation of processes that occur in a watershed which allows the prevention of the consequences of the different occurrences concerning the observed values [2]. Beven (2001) [11] defines hydrological models as a means to estimate hydrological variables in space and time, as a support for decision-making related to water resources such as flood forecasting.

An example of a hydrological model is the Topography-based Hydrological model (TOPMODEL) [12], a model developed for small basins in humid regions of the United Kingdom whose main parameter is the topography of the basin. TOPMODEL is a model classified as semi-distributed and conceptual that aggregates the advantages of the complexity of a distributed model with the simplicity of concentrated and unique parameters for the entire basin [13]. It was successfully used in several hydrologic studies in small basins (i.e. $<500 \mathrm{~km}^{2}$ ) [13]-[18] and medium and large size (e.g. 800 and 27,000 $\left.\mathrm{km}^{2}\right)$ [19] [20].

TOPMODEL's primary input variable is precipitation. The calibration efficiency and the result of any hydrological model are dependent on the accuracy 
of the measurement of this variable and, therefore, should be estimated and measured with the slightest possible error [21]. However, obtaining reliable and representative data of precipitation measures can be an overly complex task due to spatial heterogeneity and the different temporal scales of rain events [22].

Rain gauges installed on the surface directly measure precipitation. However, they have limited spatial variability representation in regions with a low equipment density [23]. Besides, tipping bucket pluviometers may underestimate the measurement in situations of very intense precipitation [24] and strong winds [25].

Indirect measurements via remote sensing such as satellite estimates are an alternative. These methods allow for greater space-temporal resolution, but as an indirect measurement of precipitation, they contain several sources of errors and uncertainties [26]. Satellite quantitative precipitations estimates (SQPE) are not effective at estimating stratiform rainfall and fail to detect convective systems due to data sampling [23]. The Climate Prediction Center Morphing Technique (CMORPH) [27] is an example of an SQPE product that uses data from passive microwave (PMW) and infrared (IR) sensors onboard satellites to produce precipitation data with high spatial-temporal resolution.

One solution to reduce precipitation errors is to use objective analysis to integrate rain gauge data with remote and spatially distributed estimates of weather radars or satellite data [21]. The Statistical Objective Analysis Scheme (SOAS) [28] was developed to combine the advantages of each measurement system to produce a precipitation analysis field with minor errors and, therefore, improving the performance of hydrological simulations. Several studies have already used SOAS to integrate precipitation data and apply them to hydrological models with satisfactory results [17] [29] [30] [31] [32]. In Pereira Filho et al. (2018) [33], a sixth-order polynomial equation of CMORPH 24-hour precipitation correlation between two pixels as a function of the distance between them was adjusted. The correlation function was adapted for the CMORPH precipitation time series from 2000 to 2015 over the entire Brazil territory. This equation made it possible to apply the SOAS method in this study.

Since TOPMODEL was developed for small-sized basins with a temperate climate, a minority of its applications have been to medium-sized basins with a tropical climate. When applying TOPMODEL to a hectare scale tropical climate basin in French Guiana, Moliĉová et al. (1997) [34] concluded that the results could be susceptible to the temporal and spatial resolution of the precipitation data. In a $73 \mathrm{~km}^{2}$ basin in Southeast Brazil, Rocha Filho (2010) [17] observed that only three parameters showed high sensitivity with the result ( $m, \ln T e$, and $t d$ ) and that the low sensitivity of the other parameters can mean a lack of adherence between the observed and calculated data [35]. When applying the model in a humid climate, $380 \mathrm{~km}^{2}$ basin in Nigeria, Campling et al. (2002) [16] changed the dynamics of the topographic index so that the water table was not parallel to the terrain. The calibration results were satisfactory and the subsurface flow was 
the most crucial process in generating the hydrograph. The authors also noted that intense convective precipitations were not properly represented by the network of rain gauges used, which corroborates the need to use precipitation measurement systems with high spatial resolution.

Because it is a simple model that each parameter (except topographic index) has a unique value for the whole basin (i.e., lumped model), TOPMODEL is a viable alternative in the operation of a flood warning system. Thus, this study aims to study the effectiveness of TOPMODEL for hydrological forecasting in the MRB, a medium-sized basin and tropical climate, a situation with a limited number of applications. For this purpose, SQPE from the CMORPH product and analyzed precipitation that integrated CMORPH data with rain gauge measurements with the SOAS method was used

\section{Material and Methods}

\subsection{Study Area}

The MRB is located in Southeast Brazil within the states of Minas Gerais (45\% of the area) and Rio de Janeiro States (55\%) with a drainage area of $8126 \mathrm{~km}^{2}$ (Figure 1). The Muriaé river is the last main tributary of the Paraíba do Sul river flowing to the Atlantic Ocean.

In this study, hydrological simulations were performed for Carangola and $\mathrm{Pa}$ trocínio do Muriaé subbasins (hereafter referred to as CLA and PMU respectively). Carangola stage level gage is at the main tributary of the eponymous river with a drainage area of $742 \mathrm{~km}^{2}$. The Patrocínio do Muriaé stage level gage is

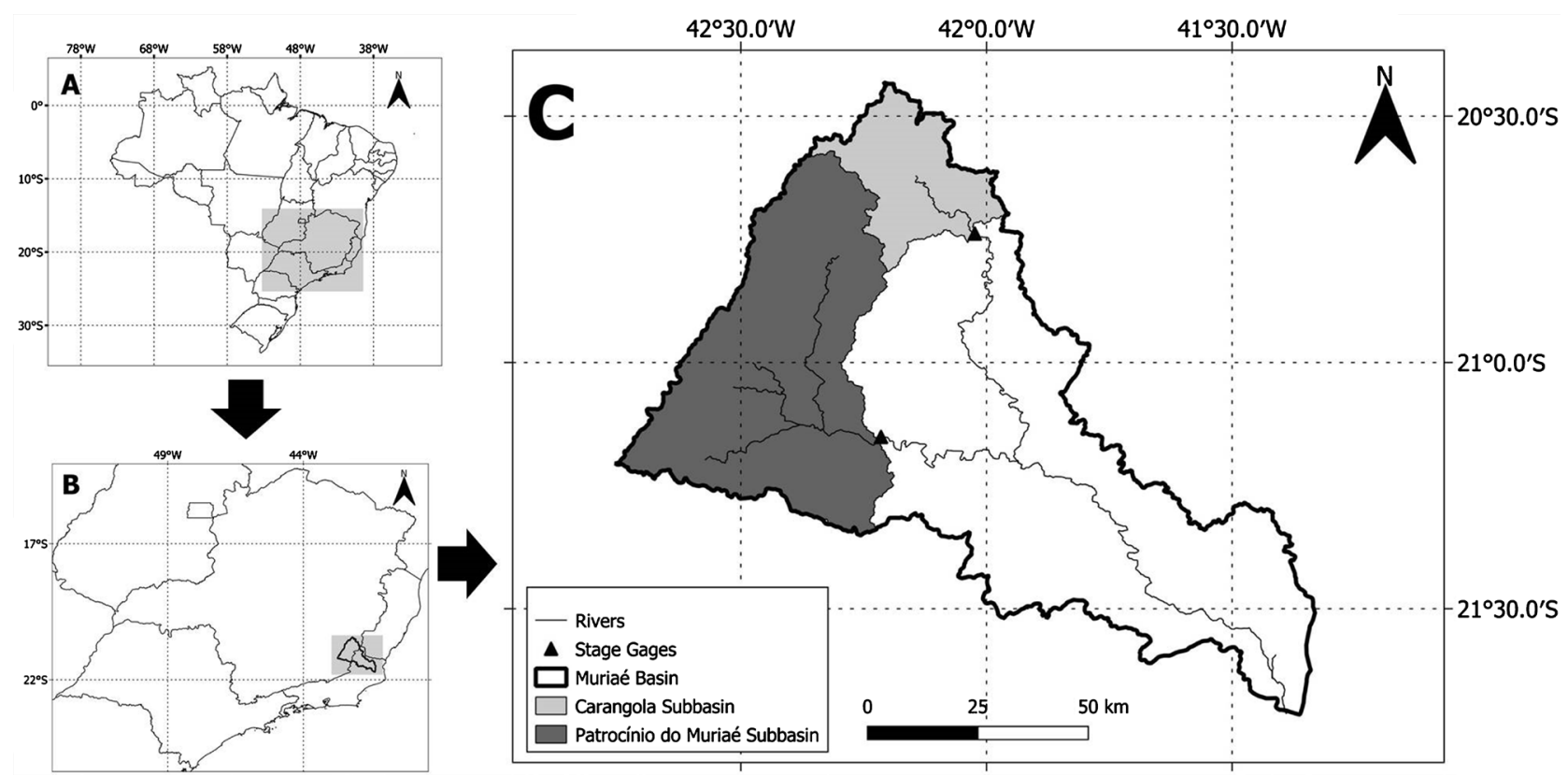

Figure 1. (A) Map of Brazil divided by federative units with an emphasis on the southeast region. (B) Southeast region of Brazil with an emphasis on the MRB location. (C) Map of the MRB (thick black line) with emphasis on CLA (light grey) and PMU (dark grey). Main rivers are represented by thin black lines. Stage gages are represented by a black triangle. Longitudes are represented on the abscissa axis and latitudes on the ordinate axis. 
at the Muriaé river and has a catchment area of $2990 \mathrm{~km}^{2}$.

The Digital Elevation Model (DEM) used was the product of the Shuttle Radar Topography Mission (SRTM) operated by the National Aeronautics and Space Administration (NASA). The images were available at 30-meter horizontal spatial resolution and 1-meter vertical resolution. In Table 1 the land use and soil type of CLA and PMU are presented. The MRB terrain (Figure 2) is characterized by rugged terrains with topographic features of $1500 \mathrm{~m}$ altitude in the northwest quadrant and flat plains in the southeast quadrant.

The region climate is classified as hot and humid with a dry winter, Köppen class Aw [37]. Temperatures are high throughout the year, with a rainy summer (December to March) and a dry winter (June to August) when monthly rainfall averages are less than $50 \mathrm{~mm}$ (Figure 3). The average annual rainfalls are 1400 $\mathrm{mm}$ (PMU) and $1200 \mathrm{~mm}$ (CLA), while the average flow values are $48 \mathrm{~m}^{3} \cdot \mathrm{s}^{-1}$ (PMU) and $13 \mathrm{~m}^{3} \cdot \mathrm{s}^{-1}$ (CLA).

\subsection{CMORPH}

The Climate Prediction Center Morphing Technique - CMORPH [27] is an SQPE with a high spatial-temporal resolution ( $~ 8 \mathrm{~km}$ and $30 \mathrm{~min})$. The method is based on precipitation rates estimated from PMW sensors. The PMW images are obtained from three sensors, located at polar orbit satellites which yield images for a specific location with a 3-hour temporal resolution (Table 2).

The IR images on board of geostationary satellites (METEOSAT and GOES) are used to increase the spatial-temporal resolution of the final product through wind vectors from the Cloud System Advection Vector (CSAV) method [41]. The wind vectors advect the PMW rainfall rate fields in space and time. Consecutive PMW images are advected forward and backward in time. In morphing, two images from the same time step are composed to generate the final product.

Table 1. Land use and soil type for CLA (second column) and PMU (third column). Sources: http://sigaceivap.org.br/siga-ceivap/map and https://www.ibge.gov.br.

\begin{tabular}{ccc}
\hline & CLA & PMU \\
Land use & & \\
Forests & $16.2 \%$ & $21.8 \%$ \\
Crops & $15.7 \%$ & $5.0 \%$ \\
Pastures & $63.1 \%$ & $69.1 \%$ \\
Urban Area & $5.1 \%$ & $3.9 \%$ \\
Soil type & & \\
Clay Soil & $18.1 \%$ & $2.3 \%$ \\
Cambisols & $1.2 \%$ & $5.5 \%$ \\
Latosols & $74.2 \%$ & $91.7 \%$ \\
Neosols & $6.5 \%$ & $0.6 \%$
\end{tabular}

${ }^{*}$ Classes defined by [36]. 


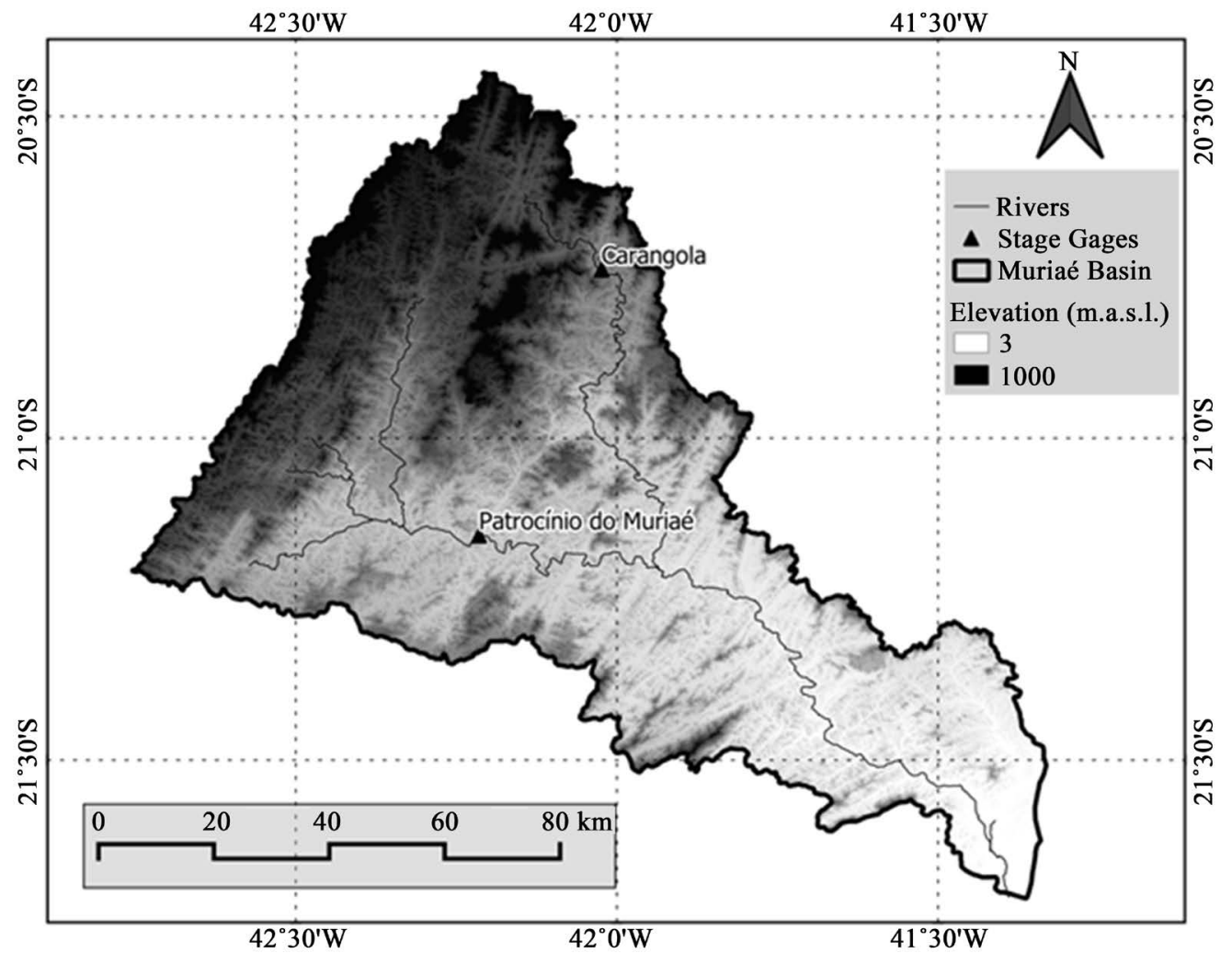

Figure 2. Digital Elevation Model (DEM) of the MRB obtained from the SRTM product. Carangola and Patrocínio do Muriaé stage gages are represented by black triangles. Altitudes are represented by the color chart (greyscale) in meters above sea level. Black lines represent the main rivers. Longitudes are represented on the abscissa axis and latitudes on the ordinate axis.

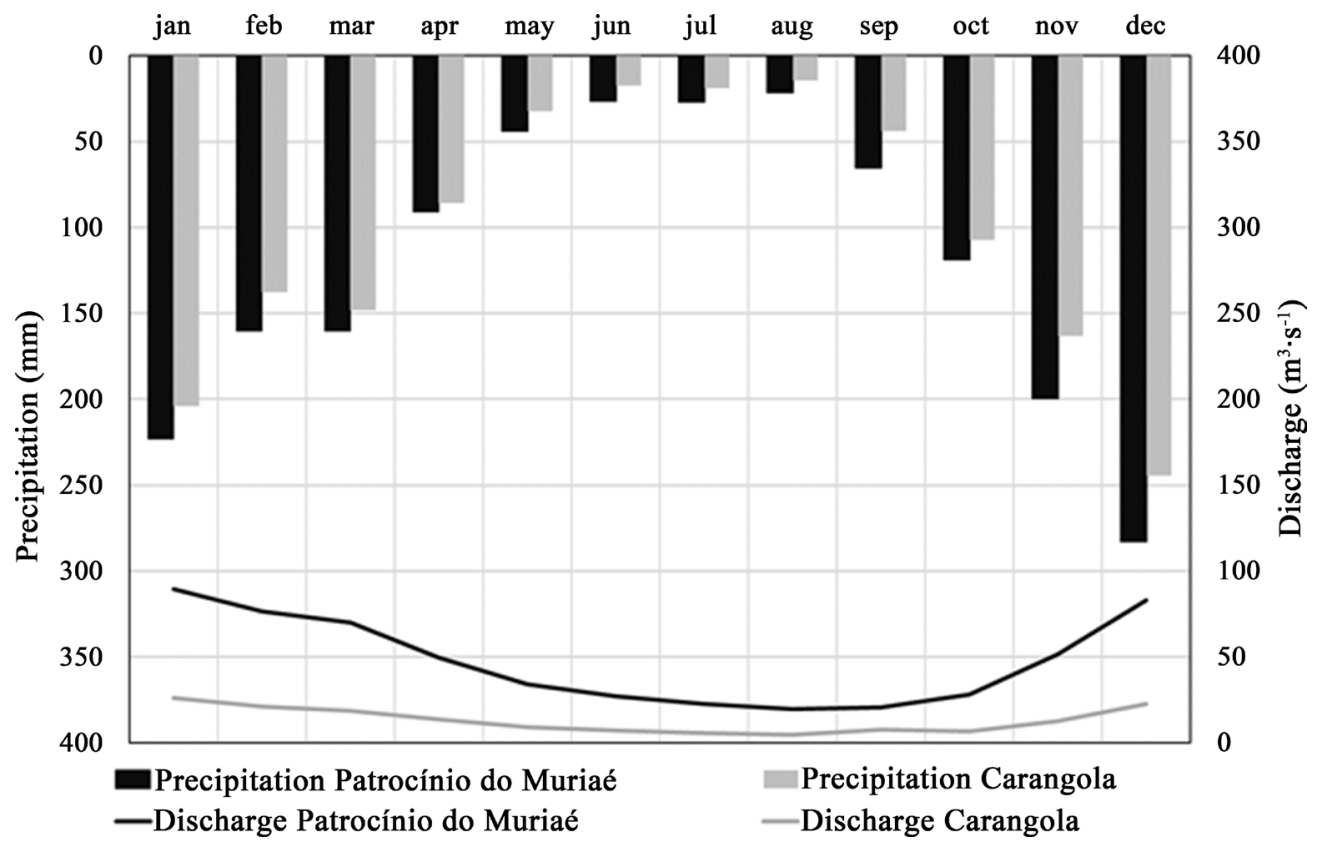

Figure 3. Climatology of Patrocínio do Muriaé (black) and Carangola (grey) hydrometeorological stations. Monthly mean precipitations $(\mathrm{mm})$ are represented by vertical bars (downward on the left ordinate axis) while monthly mean discharges $\left(\mathrm{m}^{3} \mathrm{~s}^{-1}\right)$ are represented by lines (upward on the right ordinate axis). 
Table 2. Satellite sensors used for CMORPH. Sensors, satellites, microwave frequencies, and references on respective precipitation estimates are shown.

\begin{tabular}{cccc}
\hline Sensor & Satellite & Frequencies (GHz) & Reference \\
\hline Special Sensor Microwave & DMSP & $19,22,37$ (emission based) & {$[38]$} \\
Imager (SSM/I) & & 85 (scattering based) & \\
Advanced Microwave & NOAA-15, NOAA-16, & 31 (emission-based) & {$[39]$} \\
Sounding Unit-B (AMSU-B) & NOAA-17 & 89,150 (scattering based) & \\
TRMM Microwave & TRMM & $10,19,21,27$ (emission based) & {$[40]$} \\
Imager (TMI) & & 85 (scattering based) & \\
\hline
\end{tabular}

Overland, both temperature and emissivity are highly variable, which makes the microwave background signal unpredictable and makes it difficult to use images from emission-based frequencies for precipitation estimates [42]. Therefore, over continents, PMW-based precipitation estimates rely solely on the scattering of higher frequencies microwave from frozen hydrometeors.

\subsection{SOAS}

An alternative to minimize precipitation errors is through the SOAS method [21]. An efficient interpolation technique [43] was initially developed to integrate radar precipitation estimates and rain gauge measurements. Recently, the methodology was also used to integrate SQPE [33].

The analyzed precipitation at a given grid point is obtained by adding precipitation estimates by remote sensing (radar or satellite) at the point and the sum of the product of the weights of the differences between rain gauges measurements and those estimated by remote sensing [17]. In this case, the error variance will be the sum of the squares of the differences between the measured values and the actual values. Therefore, the weights of the analyzed values will be dependent on the error variance of the precipitation estimates. The analysis is performed so that the error variance is less than the error variance of the measurements. The SOAS equation [21] is:

$$
P_{a}\left(x_{i}, y_{i}\right)=P_{r}\left(x_{i}, y_{i}\right)+\sum_{k=1}^{K} w_{i k}\left[P_{g}\left(x_{k}, y_{k}\right)-P_{r}\left(x_{k}, y_{k}\right)\right]
$$

where $P_{a}\left(x_{i}, y_{i}\right)$ is the analyzed precipitation at a point $i$ of the grid [mm]; $P_{r}\left(x_{i}, y_{i}\right)$ is the estimated precipitation by remote sensing at a point $i$ of the grid $[\mathrm{mm}] ; P_{g}\left(x_{k}, y_{k}\right)$ is the measured precipitation by the rain gauge at point $k[\mathrm{~mm}] ; P_{r}\left(x_{k}, y_{k}\right)$ is the estimated precipitation by remote sensing at point $k$ $[\mathrm{mm}] ; w_{i k}$ is the weight that will be set a posteriori; $k$ is the number of rain gauges; $(x, y)$ are the coordinates in UTM $[\mathrm{km}]$.

One premise of the method is that both rain gauge measurements and precipitation estimates are not correlated or biased. Thus, it is possible to obtain the weights through:

$$
\sum_{l=1}^{K} W_{l}\left(\rho_{k l}+\varepsilon_{k}^{2}\right)=\rho_{k i} ; \text { for } 1 \leq k \leq K,
$$

where $\rho_{k l}$ is the correlation between the rain gauges $k$ and $i$ errors; $\rho_{k i}$ is the 
correlation between point $i$ of the grid and the rain gauge $k$ errors; $\varepsilon_{k}^{2}$ is the normalized observation error; $W_{l}$ is the weight that will be set a posteriori.

The analysis error can be normalized by applying previously elaborated algorithms [44] in the error covariance matrices. The expected analysis error variance (NEXERVA) $\left(\varepsilon_{a}^{2}\right)$ can be expressed as:

$$
\varepsilon_{a}^{2}=1-\sum_{l=1}^{K} \rho_{k i} W_{l}
$$

NEXERVA is the ratio between the expected analyzed data error variance and the remote sensing estimates error variance. Thereby, it is possible to determine the spatial distribution of the errors in the analyzed field [21]. In general, NEXERVA is minimal at the rain gauge locations.

The matrix of the covariances of the estimated value errors used to normalize Equations (1) and (2) is the most crucial component of the SOAS [21]. This matrix has great importance in the accuracy of the analysis.

$$
\rho_{k l}=\frac{\left\langle\left(P_{R}^{k}-P_{a}^{k}\right) \times\left(P_{R}^{l}-P_{a}^{l}\right)\right\rangle}{\sqrt{\left\langle\left(P_{R}^{k}-P_{a}^{k}\right)^{2} \times\left(P_{R}^{l}-P_{a}^{l}\right)^{2}\right\rangle}}
$$

where $\rho_{k l}$ is the correlation between pixels $k$ and $l$ errors; $P_{R}^{k(l)}$ are the precipitation estimates by remote sensing in pixel $k(I) ; P_{a}^{k(l)}$ is the average longterm precipitation estimates by remote sensing in pixel $k(I)$.

\subsection{TOPMODEL}

TOPMODEL is a rainfall-runoff model defined as deterministic, dynamic, physical-based parameters, and semi-distributed [12]. The model was developed for small humid basins of temperate climate [45]. The model is considered semi-distributed because only the parameter related to the topography, the topographic index, is spatially distributed. The topographic index $(\lambda)$ can be expressed as $\lambda=\ln (\alpha / \tan \beta)$, where $\alpha$ is the drainage area per unit of contour and $\tan \beta$ is the terrain slope. High values of $\lambda$ indicate points more likely to reach saturation and consequently more likely to generate runoff [45]. Points with equal weights of $\lambda$ are treated as regions with similar hydrological responses.

Beven and Kirkby (1979) [12] and Beven et al. (1984) [45] described TOPMODEL as a physical-based conceptual model that represents surface and soil dynamics based on the relationship between discharge and storage established from flows in saturated zones due to slope. According to the authors, TOPMODEL combines the advantages of the simplicity of lumped models with the distributed effects of variable areas of contribution and flows through the drainage network. It is also possible to determine the parameter values from the knowledge of the physical characteristics of the hydrographic basin.

The transformation of precipitation into flow into a hydrological model can be divided into two stages: the soil water balance and the flow propagation through the basin [19]. In TOPMODEL, a series of three interconnected reser- 
voirs represents the flow generation process and is the average response of the homogeneous capacity basin: the vegetation reservoir $\left(S_{1}\right)$, the soil unsaturated zone reservoir $\left(S_{2}\right)$, and the soil saturated zone reservoir $\left(S_{3}\right)$ [17]. For each time step, the reservoirs $S_{1}$ and $S_{2}$ are filled with the levels $S_{1}^{\prime}$ and $S_{2}^{\prime}$ respectively. The saturation deficit $(S)$ of each time step is the difference between the maximum reservoir level $S_{2}\left(S_{2}^{*}\right)$ and the instantaneous level $\left(S_{2}^{\prime}\right)$.

This three reservoirs system generates four possible flows [19]: subsurface flow at the saturated zone $\left(q_{s}\right)$, vertical subsurface flow at the unsaturated zone $\left(q_{v}\right)$, surface runoff generated by infiltration excess $\left(q_{h}\right)$ (Horton mechanism), and surface runoff generated by saturation excess $\left(q_{a s}\right)$ (Dunne mechanism) [46] [47].

In the next step, TOPMODEL propagates the surface runoff for the basin outlet hydrograph composition [48]. The main processes involved in the model are presented in Figure 4.

The model uses the premise that the simulation occurs after a dry period which implies the following initial conditions [19]:

- the unsaturated soil zone $\left(S_{2}\right)$ is completely dry (i.e. $S_{2}^{\prime}=0$ );

- the discharge in the basin outlet is generated exclusively by the subsurface flow, represented by the parameter $q s 0$.

The TOPMODEL's parameters are presented in Table 3.

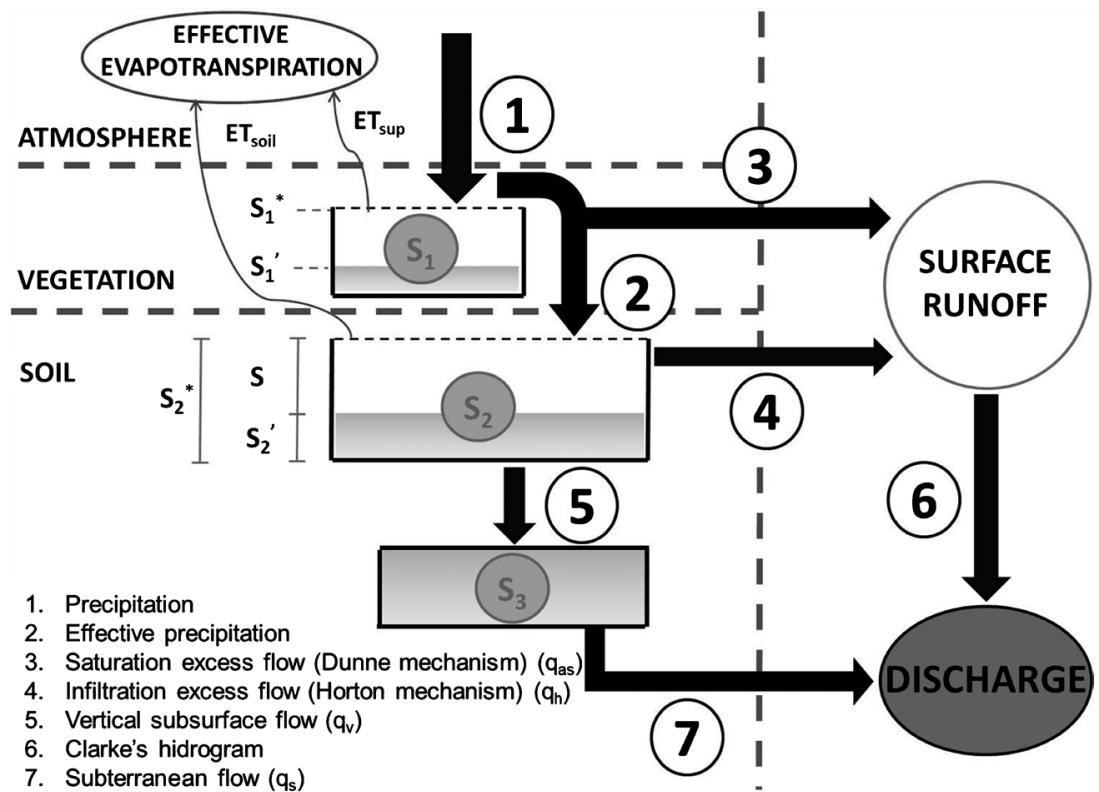

Figure 4. Schematics of TOPMODEL hydrological processes. $S_{1}$ : Vegetation reservoir; $S_{1}^{*}$ : Maximum reservoir $S_{1}$ level; $S_{1}^{\prime}$ : instantaneous level of the reservoir $S_{1}$; $S_{2}$ : unsaturated soil reservoir; $S_{2}^{*}$ : The maximum level of the reservoir $S_{2} ; S_{2}^{\prime}$ : instantaneous level of the reservoir $S_{2} ; S:$ saturation deficit; $S_{3}$ : The reservoir of saturated soil zone; $E T_{\text {sup: }}$ : Evapotranspiration that occurs on the surface; $E T_{\text {soil. }}$. evapotranspiration that occurs in the soil; (1): precipitation; (2): effective precipitation; (3): saturated area runoff; (4): Horton mechanism runoff; (5): vertical subsurface flow; (6): surface runoff propagated with Clarke's method; (7): subsurface flow. 
Table 3. List of TOPMODEL's parameters and their respective description.

\begin{tabular}{cl}
\hline Parameter & \multicolumn{1}{c}{ Description } \\
\hline$q s 0$ & Initial specific subsurface flow $\left[\mathrm{m} \cdot \mathrm{h}^{-1}\right] ;$ \\
$\ln T e$ & Effectively saturated soil transmissivity logarithm $\left[\mathrm{m}^{2} \cdot \mathrm{h}^{-1}\right] ;$ \\
$m$ & An exponential factor of the soil profile transmissivity decay $[\mathrm{m}] ;$ \\
$S r 0$ & The initial level of reservoir representing vegetation $[\mathrm{m}] ;$ \\
$S_{1}^{*}=S r \max$ & The maximum level of reservoir representing vegetation $[\mathrm{m}] ;$ \\
$t d$ & Water permanence time in the unsaturated soil zone $\left[\mathrm{h} \cdot \mathrm{m}^{-1}\right] ;$ \\
$v c h$ & Mean speed at the main channel $\left[\mathrm{m} \cdot \mathrm{h}^{-1}\right] ;$ \\
$v r$ & Mean surface runoff speed $\left[\mathrm{m} \cdot \mathrm{h}^{-1}\right]$. \\
$K 0$ & Hydraulic conductivity just below the surface in saturated soil $\left[\mathrm{m} \cdot \mathrm{h}^{-1}\right] ;$ \\
$c d$ & Capillarity drive $[\mathrm{m}] ;$ \\
$d t$ & Time step $[\mathrm{h}] ;$
\end{tabular}

\subsection{Calibration with SCE-UA}

For both subbasins, the same calibration methodology was used for all cases, the Shuffled Complex Evolution developed at the University of Arizona (SCE-UA) [49]. The methodology was developed to increase the probability that the best set of parameters found is a global minimum rather than a local minimum. The SCE-UA method was successfully used in the calibration of several hydrological models, such as NAM/MIKE 11 [50], Sacramento Soil Moisture Accounting (SAC-SMA) [51] [52], and TOPMODEL [53].

The probability of a global minimum was increased by the SCE-UA method. This method evolves multiple groups of parameter sets independently with the Competitive Complex Evolution (CCE) [49] [51]. After each round of the simulation, the parameter sets are rearranged to evolve with different partners. The simulation is repeated until the user-defined objective function of the best parameter set meets convergence criteria.

The SCE-UA calibration methodology was applied through the rtop library [54] of free software $\mathrm{R}$ (version 3.3.2). The objective function chosen was the Nash-Sutcliffe efficiency [55], which is given by:

$$
\mathrm{NSE}=1-\frac{\sum_{i=1}^{n}\left(Q_{s}^{i}-Q_{o}^{i}\right)^{2}}{\sum_{i=1}^{n}\left(Q_{o}^{i}-\bar{Q}\right)^{2}},
$$

where NSE is the Nash-Sutcliffe efficiency; $Q_{s}^{i}$ is the simulated discharge at time step $i ; Q_{o}^{i}$ is the observed discharge at time step $i ; \bar{Q}$ is the mean observed discharge of the whole period; $n$ is the number of time steps.

For the simulations, a period of 4 years was selected between 2009 and 2013. To meet TOPMODEL's premise that simulations must start in a dry period (i.e. absence of surface runoff), the month of September was defined as the beginning 
of the hydrological year. The hydrological years of 2009/2010 and 2010/2011 were chosen for calibration, while the hydrological years of 2011/2012 and 2012/ 2013 were selected for validation.

Daily rain gauge precipitation accumulation measurements between 1000 UTC (Coordinated Universal Time) of consecutive days and respective CMORPH precipitations estimates were used in the integration process with SOAS. Both rain gauges and discharge data were obtained from the Brazilian Hydrometeorological Network, which is operated by the Brazilian Water Agency (ANA). The SOAS method is described in detail in Pereira Filho et al. (2018) [33]. Evapotranspiration data were obtained from the closest weather station (Itaperuna, OMN \#83695), operated by the Brazilian National Institute of Meteorology (INMET) in which evapotranspiration is measured with a lysimeter.

\section{Results and Discussion}

\subsection{SOAS Applied to the MRB}

Fifteen (15) rain gauges were selected (Figure 5(A)) for the SOAS method at the MRB. In the expected analysis error variance (NEXERVA) results (Figure 5(B)), it can be noted the influence of the rain gauges of the pluviometers, in which the greater the proximity to the observed data, the more significant the reduction of the error variance. The NEXERVA values for CLA (0.34) and PMU (0.38) subbasins show that the SOAS methodology reduced the CMORPH estimates uncertainties by approximately $65 \%$.

\subsection{Calibrated Parameters}

The calibrated parameters of each simulation and the distribution of the topographic index of each subbasin are shown in Table 4 and Figure 6, respectively.

To comprehend the importance of each parameter, sensitivity tests were applied to all simulations (Figure 7 and Figure 8). The sensitivity analyses were

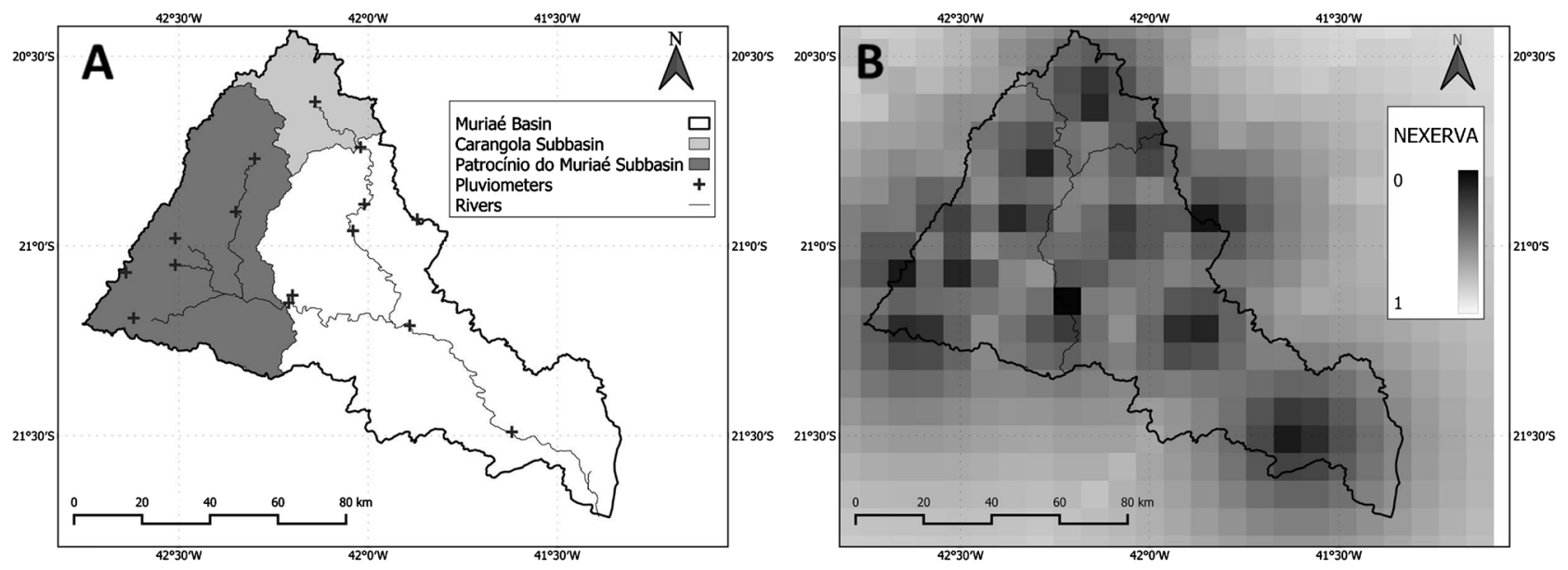

Figure 5. (A) Distribution of the fifteen (15) rain gauges used to apply the SOAS method for the MRB. Pluviometers are represented by crosses. Main rivers are represented by thin black lines. (B) NEXERVA values for the MRB. Longitudes are represented on the abscissa axis and latitudes on the ordinate axis. 
Table 4. Calibrated TOPMODEL's parameters for PMU and CLA with CMORPH and SOAS precipitation values.

\begin{tabular}{ccccc}
\hline \multirow{2}{*}{ Parameter } & \multicolumn{2}{c}{ PMU } & \multicolumn{2}{c}{ CLA } \\
\cline { 2 - 5 } & CMORPH & SOAS & CMORPH & SOAS \\
\hline $\mathrm{qs} 0\left[\mathrm{~m} \cdot \mathrm{h}^{-1}\right]$ & $4.04 \times 10^{-5}$ & $5.44 \times 10^{-5}$ & $2.22 \times 10^{-5}$ & $4.59 \times 10^{-5}$ \\
$\ln \mathrm{Te}\left[\mathrm{m}^{2} \cdot \mathrm{h}^{-1}\right]$ & $4.68 \times 10^{-1}$ & $1.38 \times 10^{-1}$ & $3.31 \times 10^{-1}$ & $1.73 \times 10^{-1}$ \\
$\mathrm{~m}[\mathrm{~m}]$ & $8.16 \times 10^{-2}$ & $9.04 \times 10^{-2}$ & $8.94 \times 10^{-2}$ & $8.05 \times 10^{-2}$ \\
$\mathrm{Sr} 0[\mathrm{~m}]$ & $2.55 \times 10^{-8}$ & $2.15 \times 10^{-8}$ & $3.44 \times 10^{-8}$ & $3.22 \times 10^{-8}$ \\
$\mathrm{Srmax}[\mathrm{m}]$ & $4.66 \times 10^{-2}$ & $2.67 \times 10^{-1}$ & $9.65 \times 10^{-3}$ & $1.04 \times 10^{-1}$ \\
$\mathrm{td}\left[\mathrm{h} \cdot \mathrm{m}^{-1}\right]$ & $1.64 \times 10^{-1}$ & $2.18 \times 10^{-1}$ & $2.81 \times 10^{-1}$ & $6.24 \times 10^{-1}$ \\
$\mathrm{vch}\left[\mathrm{m} \cdot \mathrm{h}^{-1}\right]$ & $1.17 \times 10^{7}$ & $1.57 \times 10^{7}$ & $3.59 \times 10^{5}$ & $3.44 \times 10^{5}$ \\
$\mathrm{vr}\left[\mathrm{m} \cdot \mathrm{h}^{-1}\right]$ & $1.56 \times 10^{3}$ & $1.77 \times 10^{3}$ & $1.03 \times 10^{3}$ & $1.74 \times 10^{3}$ \\
$\mathrm{k} 0\left[\mathrm{~m} \cdot \mathrm{h}^{-1}\right]$ & $2.68 \times 10^{-2}$ & $2.13 \times 10^{-2}$ & $2.80 \times 10^{-1}$ & $3.64 \times 10^{-1}$ \\
$\mathrm{~cd}[\mathrm{~m}]$ & $2.16 \times 10^{4}$ & $9.79 \times 10^{3}$ & $1.21 \times 10^{4}$ & $1.50 \times 10^{4}$ \\
\hline
\end{tabular}

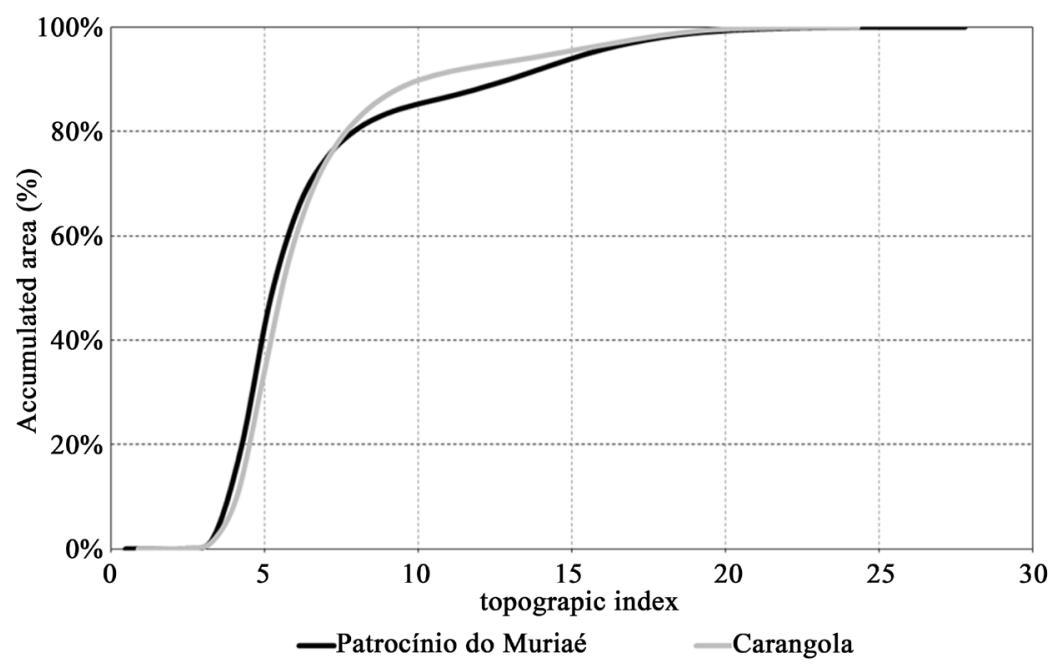

Figure 6. Variation of the accumulated area (\%) (y-axis) with the topographic index classes ( $x$-axis) for PMU (black line) and CLA (grey line).

obtained through simulations in which only a given parameter has a variable value to determine its relevance in the calibration efficiency.

It can be noted that for all four simulations, three parameters presented the greatest sensitivity: $q s 0, m$, and Srmax. The primary relevance of the parameter $m$ coincides with previous studies [17] [45], which indicates the importance of the soil transmissivity variation with depth. The significance of the parameter $q s 0$ suggests that the basin's initial condition has great importance in the model's performance. The high sensitivity of the parameter Srmax indicates the evapotranspiration importance. Higher values of Srmax for PMU are in agreement with the physical characteristics of its subbasin, which has greater forest coverage and less urban area (Table 1). The parameter $v r$ (i.e. runoff speed) had higher values with SOAS, which indicates that in this system, precipitation tends 

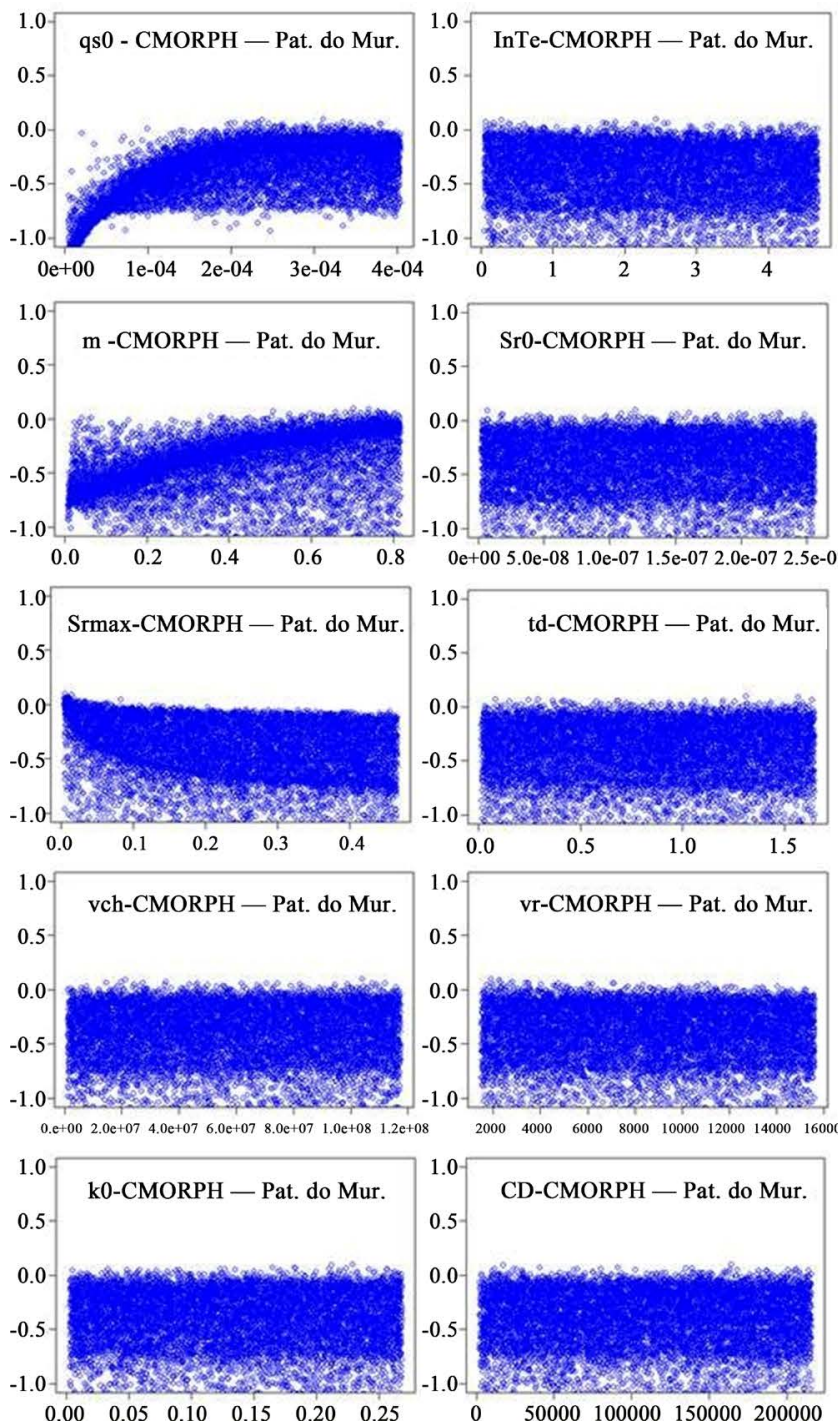
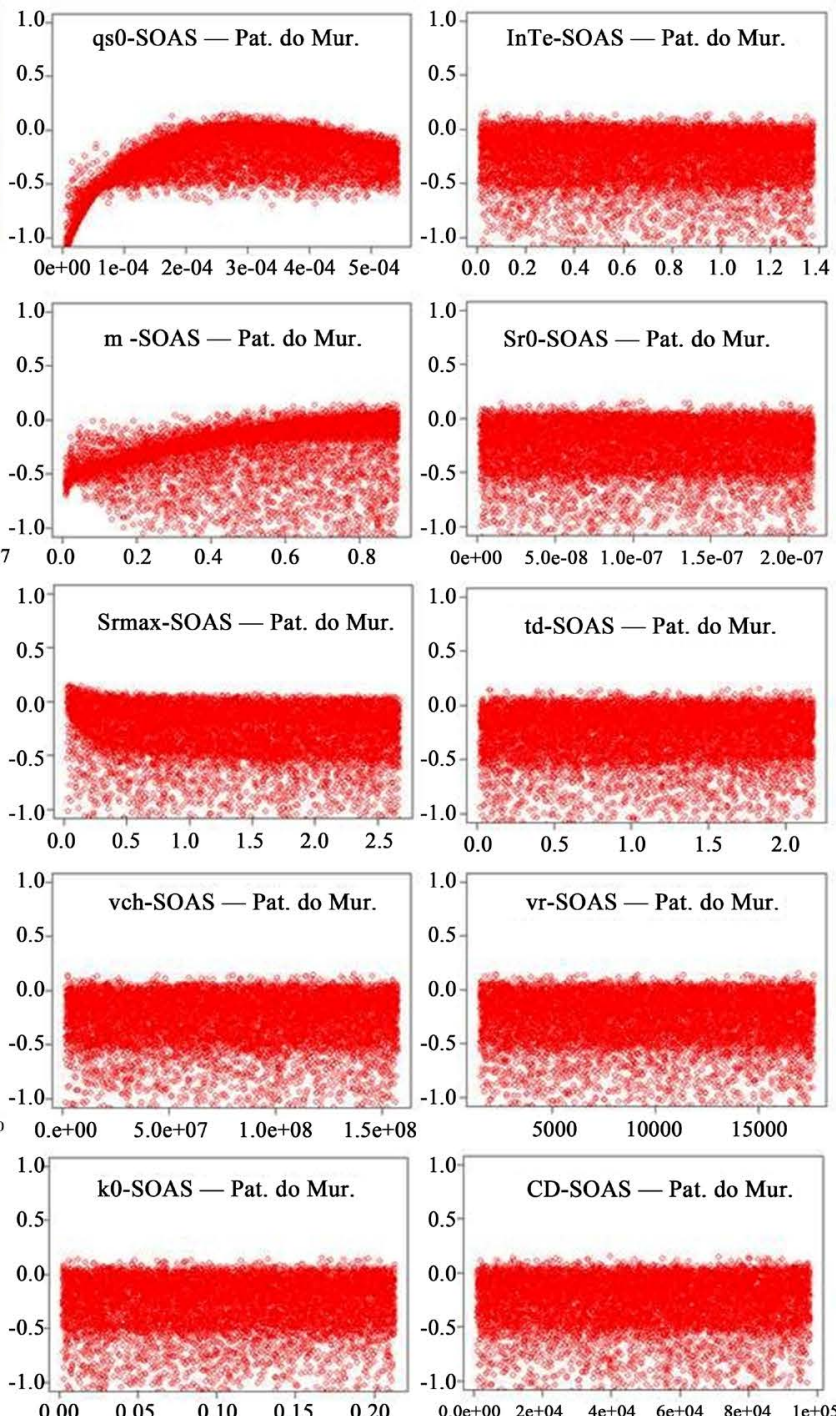

$5000 \quad 10000 \quad 15000$

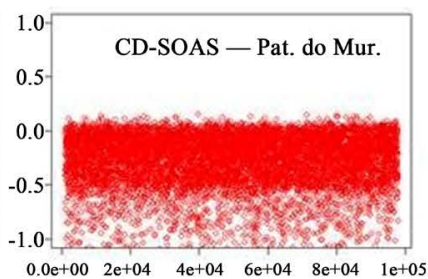

Figure 7. Sensitivity test of TOPMODEL parameters for PMU with CMORPH (blue) and SOAS (red). Parameter values are shown on the $x$-axis. Nash-Sutcliffe efficiencies are presented on the $y$-axis. Text: parameter - precipitation data system - subba$\sin$.
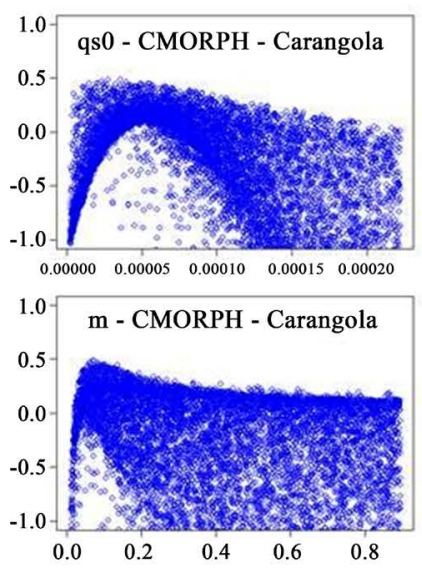
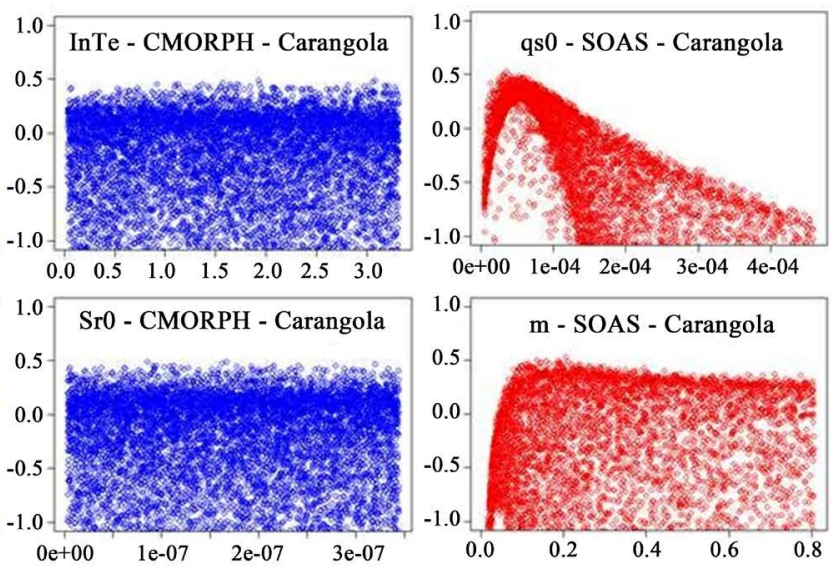

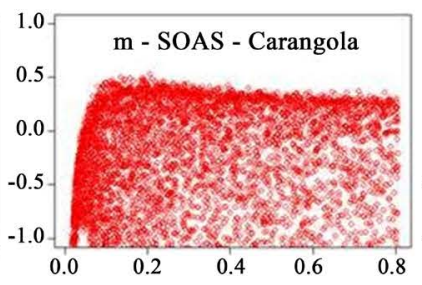

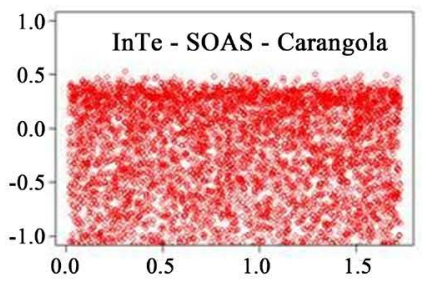

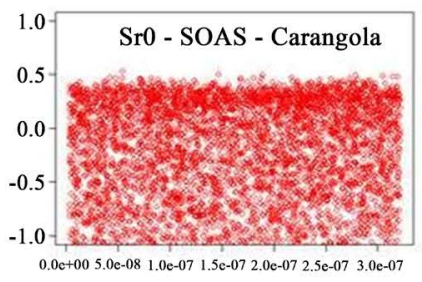



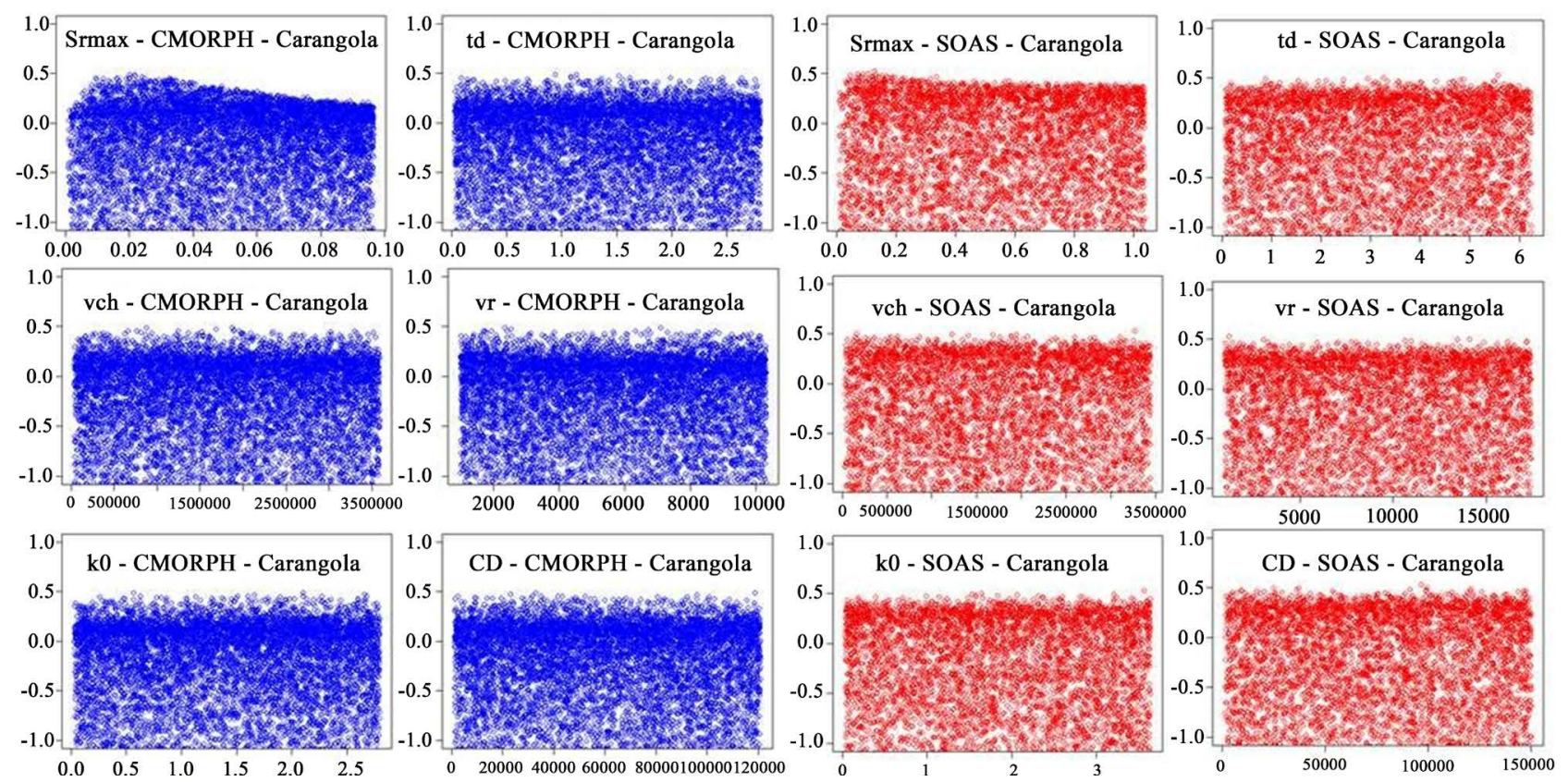

Figure 8. Similar to Figure 7 except for CLA.

to be delayed with CMORPH, which makes greater speed necessary to compensate for the shorter time.

\subsection{Simulations Performances}

In PMU, simulations with CMORPH datasets (Figure 9) yielded similar performance for both calibration $(\mathrm{NSE}=0.67)$ and validation $(\mathrm{NSE}=0.66)($ Table 5). Most peak flows were underestimated. Simulations with SOAS (Figure 10) presented higher performance for calibration $(\mathrm{NSE}=0.60)$ in relation to validation (NSE $=0.39)($ Table 5). Most peak flows were underestimated in the calibration and overestimated for validation for the hydrological year 2011/2012 and underestimated for 2012/2013.

In CLA, simulations with CMORPH (Figure 11) yielded a better result for the validation period $(\mathrm{NSE}=0.61)$ over calibration $(\mathrm{NSE}=0.54)($ Table 5$)$. In most cases, peak flows were underestimated. The fact that the validation efficiency was superior to that of calibration is an indication that the calibrated parameters satisfactorily represented the characteristics of the subbasin. In simulations with SOAS (Figure 12), the calibration period presented good efficiency (NSE = 0.85), with peak flows been well represented in the hydrological year 2010/2011 (Table 5). However, the simulations were not satisfactory for the validation period $($ NSE $=-0.04)$. In the 2011/2012 hydrological year, the peak flows were overestimated approximately $100 \%$, which explains the negative NSE value (i.e. the series mean would have been a better predictor).

For both subbasins, the highest NSE values were obtained with CMORPH data. However, in the analysis of high-level discharges (Table 6), simulations with SOAS resulted in a higher success rate (28\% and $18 \%$ for PMU and CLA respectively) compared to CMORPH (18\% and 13\%). 


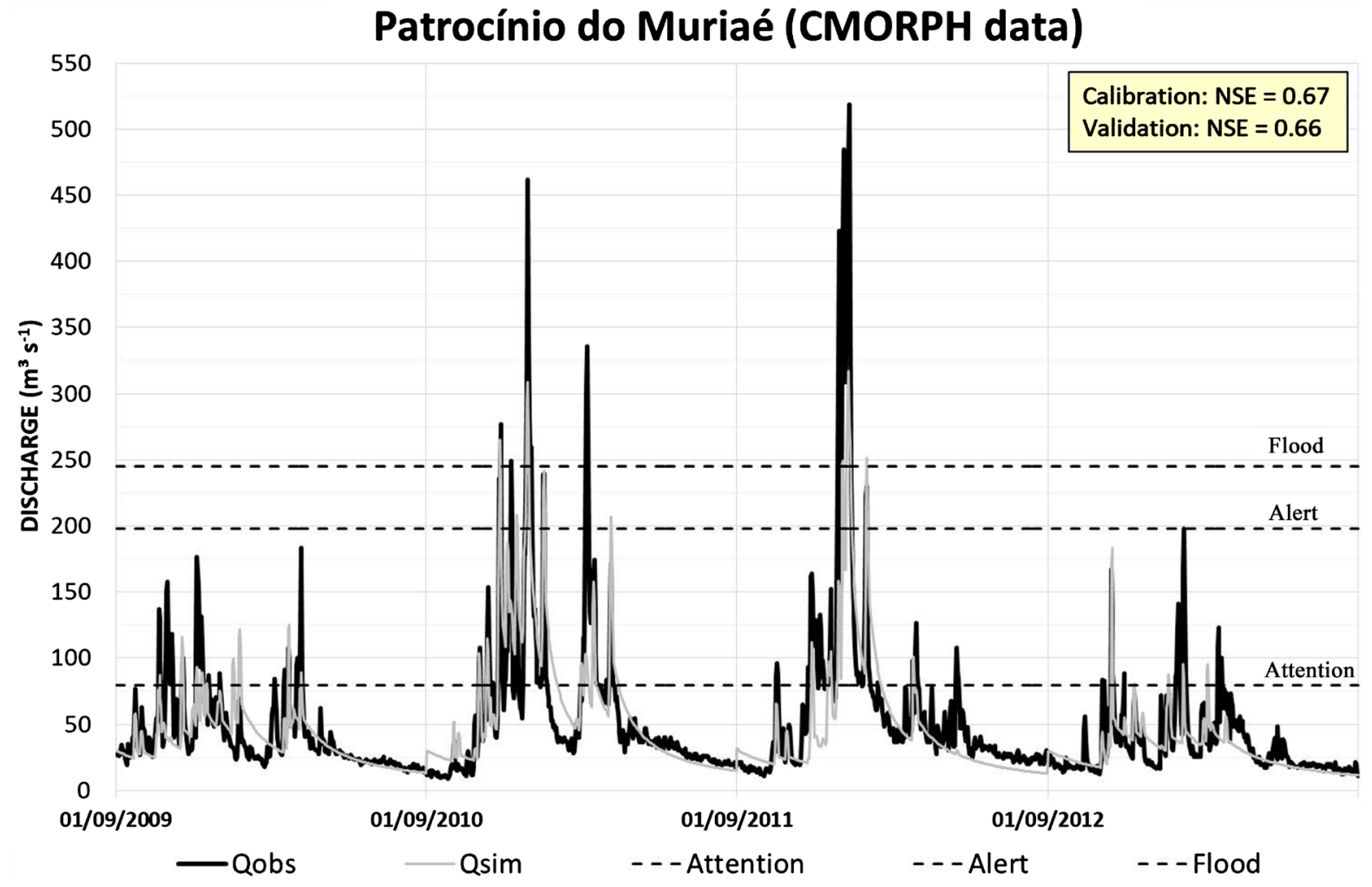

Figure 9. Discharge $\left(\mathrm{m}^{3} \cdot \mathrm{s}^{-1}\right)$ time series for PMU with CMORPH for observed (black line) and simulated (grey line) data. River stage level thresholds (attention, alert, and flood) are indicated by dashed lines. The date format is as follows: $d d / m m / y y y$.

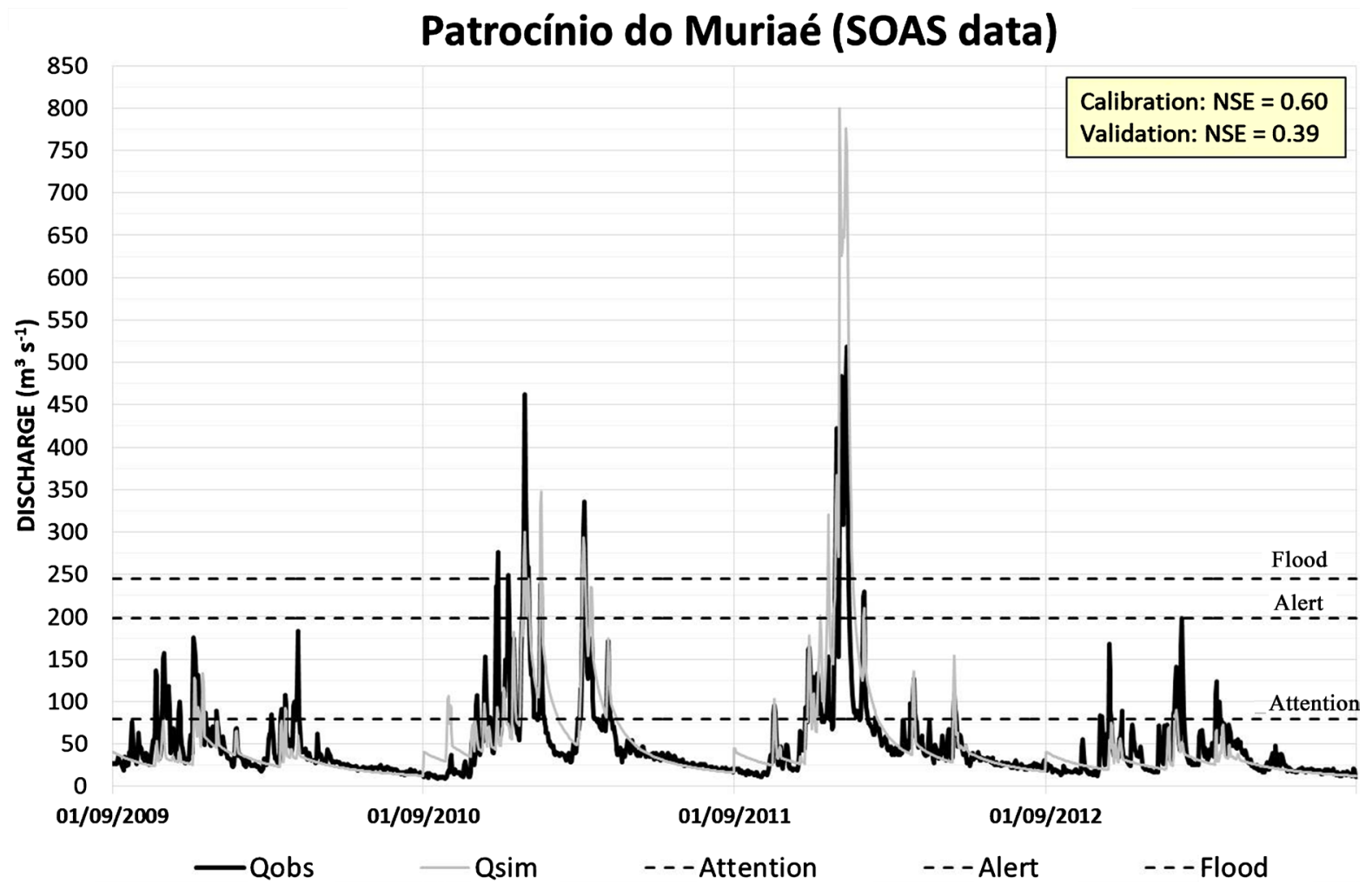

Figure 10. Similar to Figure 9 except for SOAS data. 


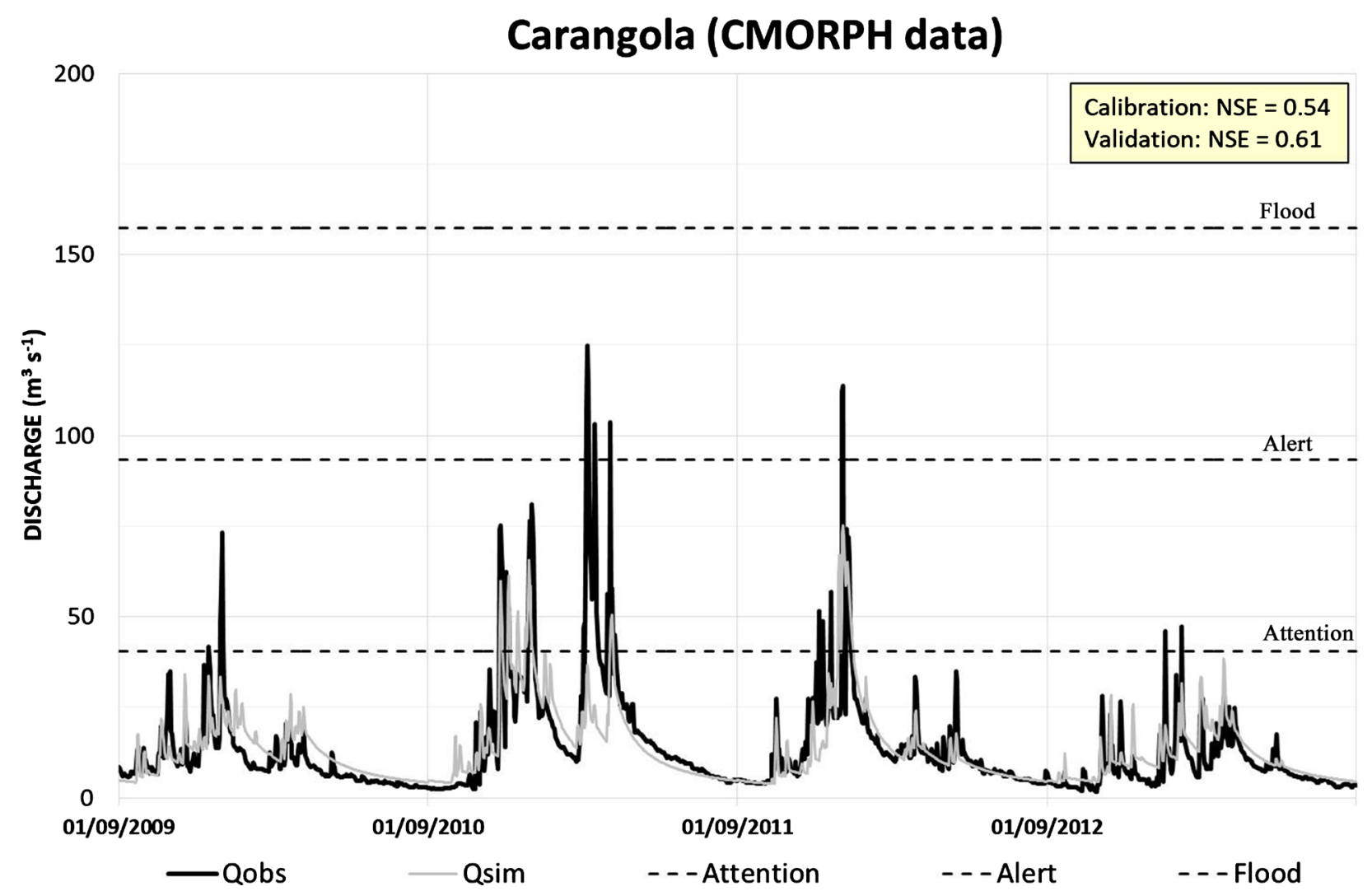

Figure 11. Similar to Figure 9 except for CLA with CMORPH data.

200

Carangola (SOAS data)

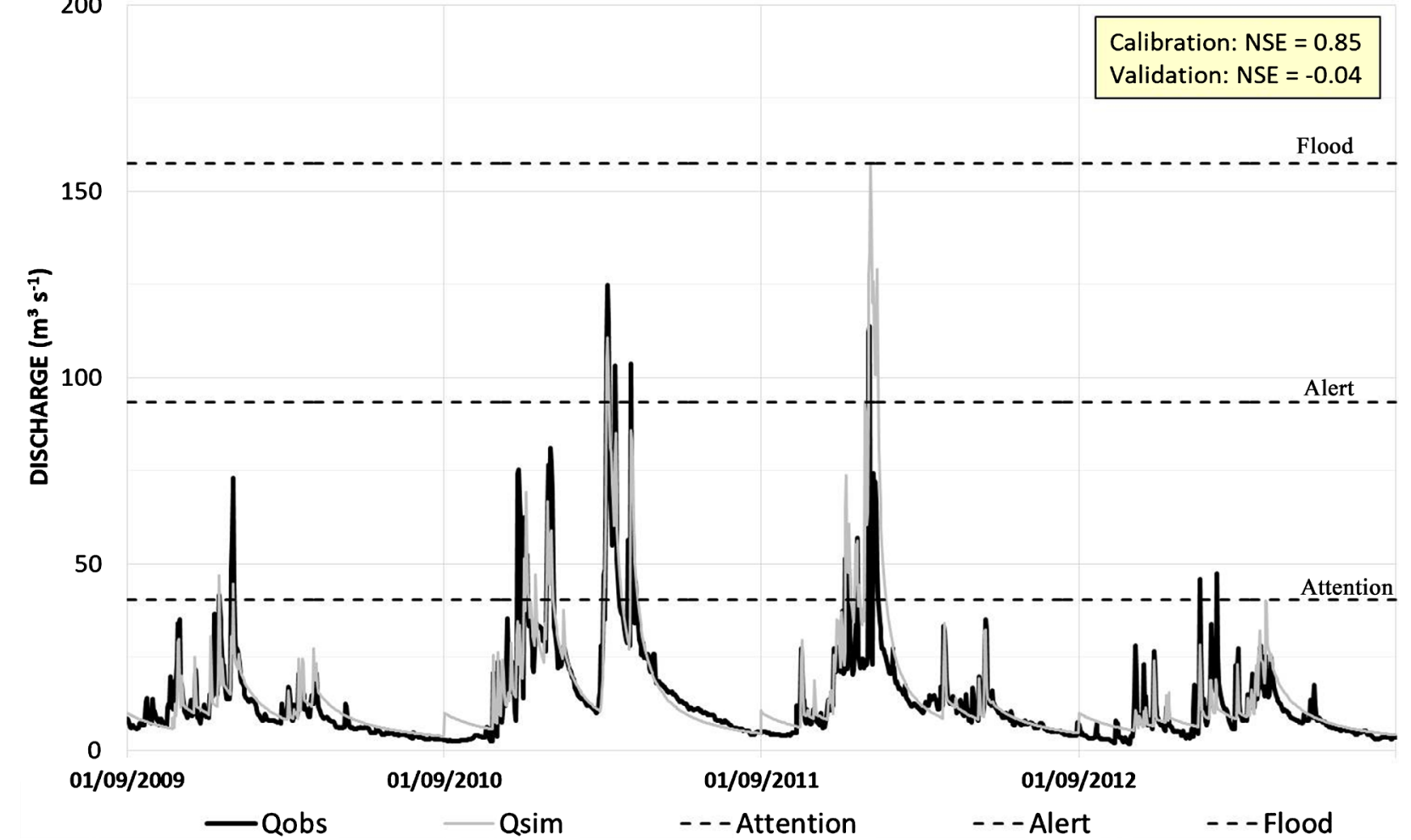

Figure 12. Similar to Figure 9 except for CLA with SOAS data. 
Table 5. NSE for TOPMODEL simulations of CLA and PMU with precipitation estimates from CMORPH and SOAS.

\begin{tabular}{ccccc}
\hline \multirow{2}{*}{ Subbasin } & \multicolumn{2}{c}{ CMORPH } & \multicolumn{2}{c}{ SOAS } \\
\cline { 2 - 5 } & Calibration & Validation & Calibration & Validation \\
\hline \multirow{2}{*}{ CLA } & 0.54 & 0.61 & 0.85 & -0.04 \\
PMU & 0.67 & 0.66 & 0.60 & 0.39 \\
\hline
\end{tabular}

Table 6. Comparative analysis of TOPMODEL simulations for CLA and PMU with precipitation estimates from CMORPH and SOAS. First line: the total number of days in which the observed discharge was higher than the attention level discharge. Second line: number of days (percentage of days) in which the model underestimated the observed discharge. Third line: number of days (percentage of days) in which the model underestimated the observed had an accurate result. The fourth line: number of days (percentage of days) in which the model overestimated the observed discharge.

\begin{tabular}{|c|c|c|c|c|}
\hline & \multicolumn{2}{|c|}{ CLA } & \multicolumn{2}{|c|}{ PMU } \\
\hline & CMORPH & $S O A S$ & CMORPH & $S O A S$ \\
\hline $\begin{array}{c}\mathrm{n}^{\circ} \text { days with observed discharge }> \\
\text { attention discharge }\end{array}$ & $67(100 \%)$ & $67(100 \%)$ & $223(100 \%)$ & $223(100 \%)$ \\
\hline $\mathrm{n}^{\circ}$ days with Deviation $<-10 \%$ & $58(87 \%)$ & $29(43 \%)$ & $139(62 \%)$ & $83(37 \%)$ \\
\hline $\begin{array}{c}\mathrm{n}^{\circ} \text { days with Deviation between } \\
-10 \% \text { and }+10 \%\end{array}$ & $5(7 \%)$ & $12(18 \%)$ & $29(13 \%)$ & $63(28 \%)$ \\
\hline $\mathrm{n}^{\circ}$ days with Deviation $>+10 \%$ & $4(6 \%)$ & $26(39 \%)$ & $55(25 \%)$ & $77(35 \%)$ \\
\hline
\end{tabular}

\section{Conclusions}

To better understand its application on medium-sized tropical climate basins, hydrologic simulations with TOPMODEL were performed on the Muriaé river basin with SQPE from CMORPH precipitation datasets and analyzed precipitation with SOAS that integrated rain gauges measurements and CMORPH estimates. Sensitivity analyses were performed to understand the relevance of each parameter to the results. For the overall period, simulated data with CMORPH had the best hydrologic simulation performance, while SOAS yielded the best simulation for high flow events (Table 6).

The results obtained in this study agree with other studies, in which only a small number of TOPMODEL's parameters showed sensitivity. The parameter $m$ relevance indicates the importance of understanding the soil transmissivity decay profile for tropical climate applications. Regarding evapotranspiration, the model showed physical significance. The more forested and least urbanized basin behaved so that the vegetation had a greater storage capacity (represented by the higher values of the Srmax parameter).

When compared to SOAS, simulated discharge values with CMORPH were significantly lower. Hypotheses for these findings are the inability of SQPE products to capture isolated convective systems due to sampling and the presence of precipitation produced by clouds without frozen hydrometeors, not detected by 
high-frequency PMW sensors (from $60 \mathrm{GHz}$ to $300 \mathrm{GHz}$ ). For high stage level periods, the simulated flows with SOAS improved because of the recovery of the amplitudes of the precipitation field with the observed data applied to the high spatial resolution $(8 \mathrm{~km})$ precipitation estimates.

However, for the entire period, simulations with CMORPH resulted in better NSE values. That was an unexpected result since the SOAS method reduced the error variance of CMORPH estimates (Figure 5). Some factors that may have contributed to this result: short simulation period (four years); uncertainties in the rate curve (which are higher for extreme stage level values in which there are fewer measurements); possible lack of accuracy in some of the rain gauges. Since SOAS yielded notably worse results at the validation stage, it can indicate that the calibrated parameters were not representative of the subbasin and behaved as empirical values to better adjust to the input data.

Thus, TOPMODEL and these new high-resolution precipitation datasets can be used in MRB hydrometeorological forecasting, provided that the initialization of TOPMODEL starts in the dry season with high-resolution precipitation datasets. Therefore, this hydrometeorological forecast improves flood warning systems for civil protection.

\section{Acknowledgements}

The authors are grateful to CPRM for providing stage and rain gauge datasets. The authors would like to thank CPC/NCEP for providing high-resolution CMORPH datasets. They also would like to thank three anonymous reviewers who enriched this manuscript. The second author is supported by Conselho Nacional de Desenvolvimento Científico e Tecnológico (CNPq) under grant 302349/20176.

\section{Conflicts of Interest}

The authors declare no conflicts of interest regarding the publication of this paper.

\section{References}

[1] Universidade Federal de Santa Catarina-Centro Universitário de Estudos e Pesquisas sobre Desastres (UFSC-CEPED) (2012) Atlas brasileiro de desastres naturais 1991 a 2010: Volume Brasil. Universidade Federal de Santa Catarina-Centro Universitário de Estudos e Pesquisas sobre Desastres, Florianópolis.

[2] Tucci, C.E.M. (1998) Modelos hidrológicos. Ed. 10, Universidade Federal do Rio Grande do Sul, Porto Alegre.

[3] Carvalho, C.S., Macedo, E.S. and Ogura, A.T. (orgs.) (2007) Mapeamento de riscos em encostas e margens de rios. Ministério das Cidades/Instituto de Pesquisas Tecnológicas-IPT. Brasília, DF, $176 \mathrm{p}$

[4] Goerl, R.F. and Kobiyama, M. (2005) Considerações sobre as inundações no Brasil. XVI Simpósio Brasileiro de Recursos Hídricos, João Pessoa, PB.

[5] Tucci, C.E.M. and Bertoni, J.C. (orgs.) (2003) Inundações urbanas na América do 
Sul. Associação Brasileira de Recursos Hídricos (ABRH), Porto Alegre, RS.

[6] Tominaga, L.K., Santoro, J. and Amaral, R. (orgs.) (2009) Desastres Naturais: Conhecer Para Prevenir. Instituto Geológico, São Paulo, 196 p.

[7] Agência da Bacia do Rio Paraíba do Sul (AGEVAP) (2007) Plano de recursos hídricos da Bacia do Rio Paraíba do Sul: Resumo: Diagnóstico dos recursos hídricos: Relatório final. Agência da Bacia do Rio Paraíba do Sul, Resende.

[8] Centro Nacional de Monitoramento e Alertas de Desastres Naturais (CEMADEN) (2020) Boletim da Sala de Situação.

[9] Xu, C.Y. (2002) Hydrologic Models. Textbooks of Uppsala University, Department of Earth Sciences Hydrology, Uppsala.

[10] Capozzoli, C. and Cardoso, A. (2020) Effects of Land Use Change on Discharge of the Paraíba do Sul River. Ciência e Natura, 42, Article No. e53.

https://doi.org/10.5902/2179460X40832

[11] Beven, K.J. (2001) Rainfall-Runoff Modeling: The Primer. John Wiley \& Sons, Hoboken.

[12] Beven, K.J. and Kirkby, M.J. (1979) A Physically Based, Variable Contributing Area Model of Basin Hydrology. Hydrological Sciences Bulletin, 24, 43-69.

https://doi.org/10.1080/02626667909491834

[13] Robson, A.J., Whitehead, P.G. and Johnson, R.C. (1993) An Application of a Physically-Based Semi-Distributed Model to the Balquhidder Catchments. Journal of Hydrology, 145, 357-370. https://doi.org/10.1016/0022-1694(93)90063-F

[14] Hornberger, G.M., Beven, K.J., Cosby, B.J. and Sappington, D.E. (1985) Shenandoah Watershed Study: Calibration of a Topography-Based, Variable Contributing Area Hydrological Model to a Small Forested Catchment. Water Resources Research, 21, 1841-1850. https://doi.org/10.1029/WR021i012p01841

[15] Iorgulescu, I. and Jordan, J.P. (1994) Validation of TOPMODEL on a Small Swiss Catchment. Journal of Hydrology, 159, 255-273.

https://doi.org/10.1016/0022-1694(94)90260-7

[16] Campling, P., Gobin, A., Beven, K. and Feyen, J. (2002) Rainfall-Runoff Modeling of a Humid Tropical Catchment: The TOPMODEL Approach. Hydrological Processes, 16, 231-253. https://doi.org/10.1002/hyp.341

[17] Rocha Filho, K.L.D. (2010) Modelagem Hidrológica da Bacia do Rio Pirajuçara com TOPMODEL, Telemetria e Radar Meteorológico. Masters Dissertation, Meteorology, Universidade de São Paulo, São Paulo.

[18] Nourani, V., Roughani, A. and Gebremichael, M. (2011) TOPMODEL Capability for Rainfall-Runoff Modeling of the Ammameh Watershed at Different Time Scales Using Different Terrain Algorithms. Journal of Urban and Environmental Engineering, 5, $1-14$.

[19] Franchini, M., Wendling, J., Obled, C. and Todini, E. (1996) Physical Interpretation and Sensitivity Analysis of the TOPMODEL. Journal of Hydrology, 175, 293-338. https://doi.org/10.1016/S0022-1694(96)80015-1

[20] Calvetti, L. and Pereira Filho, A.J. (2014) Ensemble Hydrometeorological Forecasts Using WRF Hourly QPF and TopModel for a Middle Watershed. Advances in $\mathrm{Me}$ teorology, 2014, Article ID: 484120. https://doi.org/10.1155/2014/484120

[21] Pereira Filho, A.J., Crawford, K.C. and Hartzell, C.L. (1998) Improving WSR-88D Hourly Rainfall Estimates. Weather and Forecasting, 13, 1016-1028. https://doi.org/10.1175/1520-0434(1998)013\%3C1016:IWHRE\%3E2.0.CO;2 
[22] Guo, H., Chen, S., Bao, A., Hu, J., Yang, B. and Stepanian, P.M. (2015) A Comprehensive Evaluation of High-Resolution Satellite-Based Precipitation Products over China. Atmosphere, 7, Article No. 6. https://doi.org/10.3390/atmos7010006

[23] Pereira Filho, A.J. (2004) Integrating Gauge, Radar, and Satellite Rainfall. In Online Proceedings, 2nd Workshop of the International Precipitation Working Group, CGMS-IPWG/WMO, Monterey.

[24] Legates, D.R. and DeLiberty, T.L. (1993) Precipitation Measurement Biases in the United States. JAWRA Journal of the American Water Resources Association, 29, 855-861. https://doi.org/10.1111/j.1752-1688.1993.tb03245.x

[25] Groisman, P.Y. and Legates, D.R. (1994) The Accuracy of United States Precipitation Data. Bulletin of the American Meteorological Society, 75, 215-228. https://doi.org/10.1175/1520-0477(1994)075\%3C0215:TAOUSP\%3E2.0.CO;2

[26] Di Paola, F., Casella, D., Dietrich, S., Mugnai, A., Ricciardelli, E., Romano, F. and Sanò, P. (2012) Combined MW-IR Precipitation Evolving Technique (PET) of Convective Rain Fields. Natural Hazards and Earth System Sciences, 12, 3557-3570. https://doi.org/10.5194/nhess-12-3557-2012

[27] Joyce, R.J., Janowiak, J.E., Arkin, P.A. and Xie, P. (2004) CMORPH: A Method That Produces Global Precipitation Estimates from Passive Microwave and Infrared Data at High Spatial and Temporal Resolution. Journal of Hydrometeorology, 5, 487-503. https://doi.org/10.1175/1525-7541(2004)005\%3C0487:CAMTPG\%3E2.0.CO;2

[28] Pereira Filho, A.J. and Crawford, K.C. (1995) Integrating WSR-88D Estimates and Oklahoma Mesonet Measurements of Rainfall Accumulations: A Statistical Approach. 27 th International Conference on Radar Meteorology, Vail, Boston, 9-13 October 1995, 240-242.

[29] Pereira Filho, A.J. and Crawford, K.C. (1999) Mesoscale Precipitation Fields. Part I: Statistical Analysis and Hydrologic Response. Journal of Applied Meteorology, 38, 82-101. https://doi.org/10.1175/1520-0450(1999)038\%3C0082:MPFPIS\%3E2.0.CO;2

[30] Kalinga, O., Gan, T.Y. and Xie, J. (2003) Applying Radar Rainfall Data in Basin Hydrological. In: IAHS Publication, Proceedings of Weather Radar Information and Distributed Hydrological Modelling, Held during IUGG2003 at Sapporo, No. 282, 258-267.

[31] Silva, F.D.D.S. (2006) Análise Objetiva Estatística da Precipitação Estimada com Radar medida por uma Rede Telemétrica. Tese de Doutorado, Meteorologia, Universidade de São Paulo, São Paulo.

[32] Silva, F.D.D.S., Pereira Filho, A.J. and Hallak, R. (2009) Classificação de sistemas meteorológicos e comparação da precipitação estimada pelo radar e medida pela rede telemétrica na Bacia Hidrográfica do Alto Tietê. Revista Brasileira de Meteorologia, 24, 292-307. https://doi.org/10.1590/S0102-77862009000300004

[33] Pereira Filho, A.J., Vemado, F., Vemado, G., Gomes Vieira Reis, F.A., Giordano, L.D.C., Cerri, R.I., Santos, C.C., Sampaio Lopes, E.S., Gramani, M.F., Ogura, A.T. and Zaine, J.E. (2018) A Step towards Integrating CMORPH Precipitation Estimation with Rain Gauge Measurements. Advances in Meteorology, 2018, Article ID: 2095304. https://doi.org/10.1155/2018/2095304

[34] Moliĉová, H., Grimaldi, M., Bonell, M. and Hubert, P. (1997) Using TOPMODEL towards Identifying and Modeling the Hydrological Patterns within a Headwater, Humid, Tropical Catchment. Hydrological Processes, 11, 1169-1196. https://doi.org/10.1002/(SICI)1099-1085(199707)11:9\%3C1169::AID-HYP551\%3E3. 0.CO;2-W

[35] Schuler, A.E. (2003) Fluxos hidrológicos em microbacias com floresta e pastagem na 
Amazônia Oriental, Paragominas, Pará. Tese de Doutorado, Ciências, Universidade de São Paulo, São Paulo.

[36] Embrapa (Brazilian Agricultural Research Corporation) (2006) Sistema brasileiro de classificação de solos. 2. ed. Rio de Janeiro. Centro Nacional de Pesquisa de Solos. Embrapa-SPI, Brasília, 306 p.

[37] Prado, R.B.P., Dantas, M.E., Fidalgo, E.C.C., Gonçalves, A.O., Silveira, M.D.M.L., Guimarães, P.V., et al. (2005) Diagnóstico do meio físico da bacia hidrográfica do rio Muriaé. Embrapa Solos, Rio de Janeiro, RJ.

[38] Ferraro, R.R. (1997) Special Sensor Microwave Imager Derived Global Rainfall Estimates for Climatological Applications. Journal of Geophysical Research: Atmospheres, 102, 16715-16735. https://doi.org/10.1029/97JD01210

[39] Weng, F., Zhao, L., Ferraro, R.R., Poe, G., Li, X. and Grody, N.C. (2003) Advanced Microwave Sounding Unit Cloud and Precipitation Algorithms. Radio Science, 38, Article No. 8068. https://doi.org/10.1029/2002RS002679

[40] Kummerow, C., Hong, Y., Olson, W.S., Yang, S., Adler, R.F., McCollum, J. and Wilheit, T.T. (2001) The Evolution of the Goddard Profiling Algorithm (GPROF) for Rainfall Estimation from Passive Microwave Sensors. Journal of Applied Meteorology and Climatology, 40, 1801-1820. https://doi.org/10.1175/1520-0450(2001)040\%3C1801:TEOTGP\%3E2.0.CO;2

[41] Vicente, G.A., Davenport, J.C. and Scofield, R.A. (2002) The Role of Orographic and Parallax Corrections on Real-Time High-Resolution Satellite Rainfall Rate Distribution. International Journal of Remote Sensing, 23, 221-230. https://doi.org/10.1080/01431160010006935

[42] Arkin, P.A. and Ardanuy, P.E. (1989) Estimating Climatic-Scale Precipitation from Space: A Review. Journal of Climate, 2, 1229-1238. https://doi.org/10.1175/1520-0442(1989)002\%3C1229:ECSPFS\%3E2.0.CO;2

[43] Bhargava, M. and Danard, M. (1994) Application of Optimum Interpolation to the Analysis of Precipitation in Complex Terrain. Journal of Applied Meteorology, 33, 508-518. https://doi.org/10.1175/1520-0450(1994)033\%3C0508:AOOITT\%3E2.0.CO;2

[44] Daley, R. (1993) Atmospheric Data Analysis (No. 2). Cambridge University Press, Cambridge.

[45] Beven, K.J., Kirkby, M.J., Schofield, N. and Tagg, A.F. (1984) Testing a Physically-Based Flood Forecasting Model (TOPMODEL) for Three UK Catchments. Journal of Hydrology, 69, 119-143. https://doi.org/10.1016/0022-1694(84)90159-8

[46] Betson, R.P. (1964) What Is Watershed Runoff? Journal of Geophysical Research (1896-1977), 69, 1541-1552. https://doi.org/10.1029/JZ069i008p01541

[47] Dunne, T. and Black, R.D. (1970) Partial Area Contributions to Storm Runoff in a Small New England Watershed. Water Resources Research, 6, 1296-1311. https://doi.org/10.1029/WR006i005p01296

[48] Clarke, R.T. (1973) A Review of Some Mathematical Models Used in Hydrology, with Observations on Their Calibration and Use. Journal of Hydrology, 19, 1-20. https://doi.org/10.1016/0022-1694(73)90089-9

[49] Duan, Q., Sorooshian, S. and Gupta, V.K. (1992) Effective and Efficient Global Optimization for Conceptual Rainfall-Runoff Models. Water Resources Research, 28, 1015-1031. https://doi.org/10.1029/91WR02985

[50] Madsen, H. (2000) Automatic Calibration of a Conceptual Rainfall-Runoff Model Using Multiple Objectives. Journal of Hydrology, 235, 276-288.

https://doi.org/10.1016/S0022-1694(00)00279-1 
[51] Duan, Q., Sorooshian, S. and Gupta, V.K. (1994) Optimal Use of the SCE-UA Global Optimization Method for Calibrating Watershed Models. Journal of Hydrology, 158, 265-284. https://doi.org/10.1016/0022-1694(94)90057-4

[52] Ajami, N.K., Gupta, H., Wagener, T. and Sorooshian, S. (2004) Calibration of a semi-Distributed Hydrologic Model for Streamflow Estimation along with a River System. Journal of Hydrology, 298, 112-135.

https://doi.org/10.1016/j.jhydrol.2004.03.033

[53] Ma, H.B., Dong, Z.C., Zhang, W.M. and Liang, Z.M. (2006) Application of SCE-UA Algorithm to Optimization of TOPMODEL Parameters. Journal of Hohai University (Natural Sciences), 4, 361-365.

[54] Skøien, J.O., Blöschl, G., Laaha, G., Pebesma, E., Parajka, J. and Viglione, A. (2014) Rtop: An R Package for Interpolation of Data with Variable Spatial Support, with an Example from River Networks. Computers \& Geosciences, 67, 180-190.

https://doi.org/10.1016/j.cageo.2014.02.009

[55] Nash, J.E. and Sutcliffe, J.V. (1970) River Flow Forecasting through Conceptual Models Part I-A Discussion of Principles. Journal of Hydrology, 10, 282-290.

https://doi.org/10.1016/0022-1694(70)90255-6 